Araştırma Makalesi / Research Article

\title{
GÖYNÜKLÜ BİR TARİH YAZICISI: ŞIKK-I SANİ DEFTERDARI VE HAZINE-İ BİRUN KÂTIBiI AHMED BİN MAHMUD EFENDİ
}

\author{
Hakan YILDIZ* \\ A HISTORIAN OF GÖYNÜK: THE DEFTERDAR OF \\ SECOND DIVISION, "ŞIKK-I SANİ", AND THE CLERK OF \\ THE OUTHER TREASURY, "HAZİNE-İ BîRUN" AHMED \\ BİN MAHMUD EFENDİ
}

\begin{abstract}
$\ddot{\mathbf{O} z}$
Bu çalışmada, XVII. yüzyılın ikinci yarısı ile XVIII. yüzyılın ilk yarısında yaşamış bir Osmanlı maliye bürokratı olan Göynüklü Ahmed Efendi'nin hayatı ve devlet hizmeti ele alınmıştır. Müellifin hayatı ile ilgili tespit edilebilen kaynaklar, arşiv belgeleri ve araştırmalar titizlikle incelenmiştir. Bu karşılaştırmalı inceleme sırasında, konu ile ilgili daha önce yapılan araştırmalarda görülen hatalar düzeltilmiş ve eksiklikler tamamlanmıştır. Bunun yanında müellifin değişik konulara ait notlarını bir araya getirdiği eseri "Mecmua"dan istifade edilerek, hayatı ve devlet hizmetine dair bazı yeni ve teyit edici bilgilere de yer verilmiştir. Bu suretle Ahmed Efendi'nin hayatı, doğru ve kapsamlı şekilde ortaya konulmaya çalışılmıştır.
\end{abstract}

Anahtar Kelimeler: Ahmed bin Mahmud, Göynüklü, Kâtip, Mecmua.

\begin{abstract}
The present article concerns the life and government services of Ahmed bin Mahmud Efendi of Göynük, an Ottoman official in the financial bureaucracy, who lived in the second half of the 17th and the first half of the 18th centuries. Any historical sources, archived documents and studies on the life of the author detectable have been thoroughly examined. In the course of this comparative study, errors and shortcomings of previous researches have been corrected. In addition, a revision of the "Mecmua", the collection of the author's essays on various subject matters, produced new and confirmatory knowledge about his life and public service. This article is the fruit of the effort to rectify and complete the historical knowledge on the life of Ahmed Efendi.
\end{abstract}

Keywords: Ahmed bin Mahmud, Göynüklü, Katib, Mecmua.

\footnotetext{
* Dr. Öğr. Üyesi, Nişantaşı Üniversitesi, İktisadi, İdari ve Sosyal Bilimler Fakültesi, Tarih Bölümü, e-posta: hakan.yildiz@nisantasi.edu.tr, https://orcid.org/0000-0003-4609-5087.

Makale Gönderim Tarihi : 07.06.2019 https://doi.org/10.11616/basbed.v19i49542.574007 Makale Kabul Tarihi : : 24.08.2019
} 


\section{Giriş}

XVII-XVIII. yüzyıllarda Osmanlı maliyesinin çeşitli kademelerinde görev yapan ve içinde 1711-1759 yıllarında devlet hizmetinde görüp yaşadıklarına dair bir "Tarih"in de yer aldığı Местиа ${ }^{l}$ kaleme alan Hazine-i Birun Kâtibi ${ }^{2}$ Göynüklü Ahmed bin Mahmud Efendi hakkında tarihî kaynaklarda fazla bilgi bulunmamaktadır.

Kendisine dair ilk bilgiye, Sicill-i Osmânî'de rastlanmaktadır (Süreyyâ, 1308: 256). Ardından Babinger, Osmanlı tarih yazarları ve eserleri ile ilgili bilgi verdiği kitabındaki bir dipnotta, Berlin Devlet Kütüphanesi'nde bulunan bir yazma nüshanın çok büyük bir ihtimalle Ahmed Efendi'ye ait olduğuna dikkat çekmiştir (Babinger, 2000: 341). Daha sonra Kurat, İsveç Kralı XII. Karl'ın Osmanlı topraklarında kaldığı dönem ile Prut Seferi'ni konu alan eserlerinde, sefere bizzat katılmış olan Ahmed Efendi hakkında bilgi vermiş ve onun "Tarih"inden yararlanmıştır (Kurat, 1939: 75-170; 1943: 1-31; 1951: 15-17; 1953: 741-748; 1966: 357-426).

Son dönemde ise Ahmed Efendi'nin hayatı ve eseri hakkında özellikle Başbakanlık Osmanlı Arşivi'ndeki (BOA) defter-belge kayıtları ve kısmen Berlin nüshası esas alınarak Afyoncu ve Çolak tarafindan yapılan iki araştırma bulunmaktadır. (Afyoncu, 2004: 1-8; Çolak, 1999: XI-XIII, 1-14, 50-67, 109-198; Aralık 2003: 853-864).

$\mathrm{Bu}$ araştırmada, müellifin hayatını ele alan söz konusu iki çalışmada tespit edilen bazı hususlarda düzeltmeler yapılmıştır. Ayrıca Ahmed Efendi'nin hayatı hakkında bilgi veren tüm kaynaklar ile birlikte mecmuanın Berlin ve Rado nüshalarındaki kayıtlar da ayrıntılı olarak taranıp değerlendirilerek, müellifin resmî görevleri hakkında bazı ek bilgilere ulaşılmıştır. Bu suretle Göynüklü Ahmed Efendi'nin hayatı, mevcut tüm belge ve bilgilerin ışığında aydınlatılmaya çalışılmıştır.

\section{Göynüklü Ahmed Efendi'nin Hayatı ve Devlet Hizmeti}

\subsection{Doğum Yeri ve Tarihi}

Ahmed Efendi, hem eserindeki kayda hem de diğer kaynaklara göre bugün Bolu ilinin bir ilçesi olan Göynük'lüdür (Göynüklü Ahmed

\footnotetext{
${ }^{1}$ Bundan sonra "Berlin Nüshası" ya da kısaca $B N$ olarak adlandırılacaktır.

2 Defterdarlığa bağlı olarak hazine-i birun/dlş hazine de denilen devlet hazinesine giren tüm gelirlerin ve bu hazineden çıkan tüm ödemelerin kayıtlarını tutan mali konular ve hesaplamalarda uzmanlaşmış kâtip (Orhonlu, 1998: 130131). 
Efendi'ye hll'at-i fāhire ilbās: BN, 361b/463b). ${ }^{3}$ Babasının memleketi olması sebebiyle ya da orada doğup daha sonra İstanbul'a gelmiş olduğu için Göynüklü lakabıyla anılmıştır (KK.d, 0261-6: 16; A.RSK.d, 1571: 1; Süreyyâ, 1308: 256; Vâsıf, 1219: 156). Yine eserindeki kayıtlara göre babasının ismi Mahmud'dur (Ahmed ibn Mahmūd, kātib-i hazīne-i bìrün: $B N, 63 b, 277 \mathrm{a} / 195 \mathrm{a} ; 89 \mathrm{a} / 79 \mathrm{a}, 90 \mathrm{~b} / 80 \mathrm{~b})$.

Doğum tarihi hakkında, ne kendi eserinde ne de diğer kaynaklarda kesin bir bilgi yoktur. Ancak Sicill-i Osmânî ile Vâsıf Tarihi, ölümünde yüz yaşını aşkın olduğu bilgisini vermektedir (Sinni, yüzü tecāvüz etmişidi: Süreyyâ, 1308: 256; müsinn ü ihtiyār ve yüz yaşını mütecāviz bir pirr-i emekdār olup, bu esnāda hulūl-i ecl mev'ūdily]le vefāt: Vâsıf, 1219: 156). Ayrıca Sicill-i Osmânî'de, Mart-Nisan 1759 tarihinde vefat ettiği kaydı vardır (Süreyyâ, 1308: 256). Bu bilgilerden hareketle, Ahmed Efendi'nin tahminen IV. Mehmed'in saltanat dönemine (1648-1687) rastlayan 1649-1658 yıllarında doğduğu söylenebilir. ${ }^{4}$

\subsection{Kâtiplik Mesleğine Girişi}

Ahmed Efendi'nin muhtemel doğum tarihi ile memuriyetine dair eserinde ilk bilgi verdiği 1687 senesi arasındaki dönem, yani 29 yaşından 38 yaşına kadar; çocukluğu, gençlik dönemi, hatta orta yaş başlangıcına kadar hayatı ve devlet hizmeti hakkında ne kendi eserinde ne de diğer kaynaklarda herhangi bir bilgi yoktur. Sadece Sicill-i Osmânî'de, maliyeden yetiştiği kaydı vardır (Süreyyâ, 1308: 256) Kuvvetle muhtemeldir ki; XVII. yüzyılın ikinci yarısındaki bürokratik teamül doğrultusunda, maliye teşkilatında ya da başka bir devlet hizmetinde çalışan akrabası ya da aile dostunun ilgili makamlara tavsiyesi/ricasıyla, kâtip olarak yetiştirilmek üzere 8-10 yaşlarında Osmanlı merkez maliye

\footnotetext{
${ }^{3} B N^{\prime}$ nın bazı sayfalarının sırası, ciltlenirken ya da başka bir sebeple karışmıştır. Dolayısıyla nüshanın varakları; biri Arap rakamları ile müellif eliyle, diğeri de çok daha sonradan eksik ve yanlış dizilişi düzeltmek amacıyla bir başkası tarafından günümüz rakamlarıyla olmak üzere iki türlü numaralandırılmıştır. Yukarıdaki ve bundan sonraki varak numaralarında ilk numara, karışan Arabî varak numarasını düzeltmek için sonradan eklenen numarayı; eğik çizgiden sonraki rakam ise müellifin Arabî rakamını göstermektedir.

${ }^{4}$ Romen tarihçilerinden Adrian Tertecel, Prut Seferi'nin birincil kaynaklarından Ahmed bin Mahmud'un mecmuası ile ilgili makalesinde Ahmed Efendi'nin doğum tarihini "yaklaşık olarak 1680" olarak belirtmiş, ama söz konusu tarihi hangi kaynak veya bilgiye göre tespit ettiğine dair bir açıklama yapmamıştır (Tertecel, 1994: 202[2]). Yukarıda zikredilen kaynaklara ait belgelere ve bu bilgilere göre "yaklaşık olarak" dahi olsa 1680 tarihini doğru kabul etmek mümkün değildir.
} 
teşkilâtı olan "defterdarlık" bünyesindeki kalemlere alınmıştır. Bir müddet bekledikten sonra da boşalan kadro ile şâkirdliğe (kâtip çıraklığı) terfi etmiş olması gerekir. Yıllarca kalabileceği bu kadroda, bir yandan kıdemli bir kâtip ya da âmirin yanında kitâbet, inşâ, hesap, defter tutma gibi konularda eğitim görürken, diğer yandan da kâtiplere defter ya da evrak getirip götürmüş olmalıdır (Afyoncu ve Ahıskalı, 2002: 53-55; Afyoncu, 2014: 107-130).

Bununla birlikte müellifin bu hizmet dönemine denk gelen XVII. yüzyılda kalemlerdeki personel sayısının artışına paralel olarak, şâkirtlikten kâtipliğe terfi edebilmek için boş kadro bulabilmenin çok zorlaştığı ve şâkirtlerin sadece \%2'sinin kâtip olabildiği görülmektedir (Afyoncu, 2014: 129). Dolayısıya söz konusu çok düşük yüzdelik dilime girerek kâtip olmayı başaran Ahmed Efendi'nin, kâtiplerde aranan ketumluk, namusluluk, dürüstlük, zekâ, yetenek ve başarı gibi özelliklerin biri ya da bir kaçının kendisini emsalleri arasında öne çıkarması suretiyle arzuhaliyle veya defter emini arzıyla (Çetin, Aralık 1992: 41 ve Ocak 1993: 39; Afyoncu ve Ahıskal1, 2002: 53) terfi etmiş olmalıdır. ${ }^{5}$

Kâtip olarak göreve başladığı yer, devletin şer'î ve örfî gelirlerinin toplandığı, kayitlarının tutulduğu ve her türlü yazışmasının hazırlandığı maliye hazinesi ya da dış hazine de denilen (Uzunçarşı1l, 1984: 394) "hazîne-i bîrûn"; ilk görevi de "hazine-i birun kâtipliği"dir. Eserindeki "hazìne-i bìrūn kätibi ber-vech-i te'bìd üzerimizde olup" ifadesi (BN, vr. 266b/306b; KK.d, 0261-6: 166), kâtipliğe başlamasından vefatına kadar hazine-i birun kâtipliğinin uhdesinde olduğunu göstermektedir.

Kâtipliğe hangi yıl başladığı hakkında bir bilgi yoktur. Ancak IV. Mehmed ile II. Mustafa'nın tahttan indirilmesi olaylarına bizzat şahit olduğuna dair ayrıntılı ifadesine (Bu hakīr, Sultān Mehemmed Vak'ası'nı mufassal görüp; zorbaların keyfiyyet-i ahvālini dahı geregi gibi görmüş idim. Ve Sultān Mustafā Vak'ası'nı dahı görmüş idim: BN, 324a/412a) göre, ${ }^{7}$ en azından 1687-1703 yıllarında devlet hizmetindedir.

\footnotetext{
${ }^{5}$ Göreve başlayan her kâtip, yanında daima küçük bir not defteri taşırdı. İşâ defteri de denilen yaklaşı 10 x $18 \mathrm{~cm}$ ebadındaki bu defterde; unutulma ihtimali olan önemli bilgilere gerektiğinde ulaşabilmek için yazışma örnekleri, yazıların muhatabı olan memurların elkap, unvanları ve diğer önemli bilgilere ait kısa notlar bulunurdu (Çetin, Aralık 1992: 41).

${ }^{6}$ Bkz. Ek 1. Afyoncu, makalesinde bu belgeyi hatalı olarak "A.RSK.d, nr. 261/6, 7" şeklinde okumuştur (2004: 5).

${ }^{7}$ Ahmed Efendi'nin zikrettiği Sultān Mehemmed Vak'ası, IV. Mehmed'e karşı isyan ve gelişen hadiselerin bir sonucu olarak, 9 Kasım 1687 tarihinde padişahın tahttan indirilmesi olayıdır (Silâhdâr 1928: 295-298). Birinci Edirne Vak'as1 846
} 


\subsection{Osmanlı Maliyesinin Çeşitli Bürolarındaki Hizmeti ve Görevleri}

Göynüklü Ahmed Efendi, 1703 yllında tahta geçen III. Ahmed'in saltanatında da devlet hizmetine aralıksız devam etmiş olmalıdır. Afyoncu, konu ile ilgili makalesinde, BOA'deki tevcîhât kayıtlarında sadrazam masraf kâtibi olması dolayısıyla 3 Ağustos 1705-7 Mayı 1706 tarihlerinde aynı zamanda bir hacegânlık olan haslar mukataacılığı yapan, (A.RSK.d, 1562: 118) 11 Nisan 1707-30 Eylül 1708 tarihlerinde mevkufatçılık hizmetinde bulunan (A.RSK.d, 1562: 20) ve 11 Aralık $1710^{\prime 8}$ da küçük ruznamçeciliğe tayin edilen (A.RSK.d, 1562: 100) bir Ahmed Efendi'nin varlığına dikkat çekmekle birlikte, bu kişinin Göynüklü Ahmed Efendi olup olmadığının kesin olarak bilinemediğini belirtmektedir (2004: 2). Bununla birlikte, 1707-1708 tarihlerinde meslekte olgunluk dönemi sayılabilecek ellili yaşlarda olan mevkufatçılık görevindeki Ahmed Efendi'den bir rü'ûs kaydında "emektār" diye bahsedilmesi (Mevkūfätçılık, emektārlardan Ahmed Efendi'ye verildi, fì 8 M 119: A.RSK.d, 1562: 20) ve Sicill-i Osmânî'de maliyeden yetişmiş olduğuna dair bilgi (Süreyyâ, 1308: 256) ile tevcihat kaytllarında sadrazam masraf kâtipliği, haslar mukataacılığı, mevkufatçılık, küçük ruznamçecilik ve hazine-i birun kâtipliği gibi maliye kaleminin çeşitli şubelerine ait memuriyetlerinin uyuşması, söz konusu kişinin Göynüklü Ahmed Efendi olabileceğine dair ihtimali kuvvetlendirmektedir.

1711 y1linda ek görevlere atanmayan Ahmed Efendi, sadece hazine-i birun kâtipliği yapmış ve aynı yıl Osmanlı-Rus savaşına (Prut Seferi) da bu görevle katılmıştır ( $B u$ hakīr, bu vakitde hazine-i bìrūn kātibi bervech-i te'bìd üzerimizde olup: BN, 266b/356b). Daha sonra Mora Seferi'nin dönüş yolunda 23 Eylül 1715 tarihinde hazine-i birun kâtipliği vazifesine ek olarak piyade mukabeleciliği ile görevlendirilmiş̧ir (sefer- $i$ hümāyūn takrībi[y]le piyāde mukābelecigi dahı zamm olunmuşdu: $B N$, 266b/356b).

Mecmuasındaki kayıtlara göre, 27 Eylül 1716'da tekrar mevkufatçılığa tayin edilmiş $(B N$, 283a/373a; A.RSK.d, 1562: 20); 23 May1s 1717 tarihinde ise vazifesinden azledilmiştir $(B N, 287 \mathrm{~b} / 377 \mathrm{~b}$; A.RSK.d, 1571:

adıyla da anılan Sultân Mustafâ Vak'ası ise cebecilerle ilgili bir ısyan hareketi sonucunda, II. Mustafa'nın hal edilerek yerine kardeşi III. Ahmed'in tahta çıkarılması (23 Ağustos 1703) ile ilgili olaylardır. (Râşid, 1282: III, 11-78; Uzunçarş111, 1982: IV/1, 24-45; Aktepe 1989: 34).

8 Afyoncu bu tarihi yanlışlıkla 7 Mayıs 1710 (8 Rebiyülevvel 1122) olarak okumuştur. 
26; KK.d, 0261-6: 1699). Buna rağmen bizzat katıldığı 1716-1717 Osmanlı-Avusturya savaşlarında ${ }^{10}$ hazine-i birun kâtibi olarak görev yaptığına dair kayıtlara göre, söz konusu görev yine uhdesine kalmıştır (Ahmed Efendi, kätib-i hazine-i bìrün...fi 8 ZA Sene 1128: BN, 277b 1367b; fì 2 Receb Sene 1129...Taşra Hazīne Kātibi Ahmed Efendi; ve tārīh-i varakaya gelinceye bu hakīr bir seferden kaldiğımı yoğiken, bu sene-i mübārekede bā-fermān-l 'ālì rikāb-l hümāyūnda alıkonulup ve sefer-i hümāyūna rikāb-ı hümāyūn ile gitmek üzere hazīne kitābetinde istihdām buyurdular: $B N, 288 \mathrm{a} / 378 \mathrm{a})$.

Ahmed Efendi, 12 Mayıs-11 Eylül 1718 tarihleri arasında küçük evkaf muhasebecisidir (A.RSK.d, 1562: 111).

Daha sonra 20 Aralık 1718 günü silâhdarân kitâbeti görevine getirilmiş (BN, 295b/385b), 18 Ağustos 1720 tarihinde de cebeciler kâtibi olmuştur (Cebeciler kitābeti, hazīne kātibi olup sāblkā Silahdār Kātibi Ahmed Efendi'ye: $\left.{ }^{11} B N, 296 \mathrm{a} / 386 \mathrm{a}\right)$.

20/22 Temmuz 1722 tarihinde hazine kâtipliği görevi ile birlikte ifa ettiği cebeciler kâtipliğinden büyük kale tezkireciliğine tayin edilen Ahmed Efendi, ${ }^{12}$ bir yıl sonra 24/26 Temmuz 1723 tarihinde azledilmiştir ${ }^{13}$ (A.RSK.d, 1571: $21^{14}$ ).

İki y1l kadar sonra 24 Haziran 1725 tarihinde tevcih edilen piyade mukabeleciliği görevini (Bu hakīin hissesine iki sene ma'züllukdan sonra piyāde mukābeleciliği ināyet buyuruldu: BN, 302b/392b) ise 9 Haziran 1726'ya kadar sürdürmüştür (A.RSK.d, 1571: 21).

\footnotetext{
${ }^{9}$ KK.d, 0261-6'da 16. sayfada olan bu kayıt, Afyoncu tarafindan hatalı olarak 7. sayfada göstermiştir (2004: 2).

${ }^{10} \mathrm{Bu}$ savaşlar için bkz. Uzunçarş1l1, 1982: 109-142; Zinkeisen, 2011: 359-407; Jorga, 2005: 281-294; Hammer, 2003: 192-212; Râşid, IV, 1282: 193-376.

${ }^{11}$ Çolak, bu kaydı hatalı olarak "Sâbıka Silâhdâr Kâtibi Ahmed b. Mahmud'a" şeklinde okumuştur (1999: 4, dipnot: 17).

12 20-21. satırlardaki "Hazine Kâtibi Ahmed Efendi" ifadesi, Çolak tarafindan hatalı olarak "Hazine kâtibi Ahmed b. Mahmud'a" şeklinde okumuştur (1999: 4, dipnot: 19).

${ }^{13}$ XVIII. yüzyıldan itibaren kalemlerdeki kâtip sayısının artması nedeniyle tayin ve aziller yıllık olarak şevvâl ayında yapılmakla birlikte, bir yılı doldurmadan da olabilmekteydi. Bu durumda olup görevine devam etmesi istenilen kâtipler ya da hacegân, şevvâl ayında memuriyetlerinde "ibkâ" edilirdi (Afyoncu, 2014: 91, $100,119)$.

${ }^{14}$ Afyoncu, Ahmed Efendi'nin büyük kale tezkireciliği görevinde bulunduğu döneme kaynak olarak gösterdiği A.RSK.d, 1571'in 21. sayfasını yanlışlıkla "s.11" olarak vermiştir (2004: 2, dipnot: 17). 
$\mathrm{Bu}$ tarihten 1730 y1lına kadar geçen yaklaşık dört senede, Ahmed Efendi'nin hangi memuriyetlerde bulunduğuna dair bilgi yoktur. 27 Nisan 1730 tarihinde İran Safevî Şehzâdesi Sâfî Sultan'ın sadrazamın huzuruna kabulü dolayısıyla yapılan törende, üçüncü defa cebeciler kâtibi olmuştur (bu hakīr, üçüncü def'a da yine cebeciler kātibi bulunduğumuz hasebiyle: $B N, 319 \mathrm{~b} / 407 \mathrm{~b}){ }^{15}$

Tevcihat kayıtlarına göre Ahmed Efendi, 27 Nisan'dan sonraki yaklaşık üç ay içinde tekrar hazine kâtipliğine tayin edilmiş; 1 Ağustos 1730 tarihinde de ek olarak ikinci kez büyük kale tezkireciliği ile birlikte küçük ruznamçe vekilliği tevcih edilerek İran seferine katılması emredilmiştir (Zikr olunan tezkirecilik [tezkirecilik-i kale-i kebīr] ve vekālet-i rūznāmçe-i küçük, Hazīne Kātibi Ahmed Efendi'ye verildi: A.RSK.d, 1571, $21 ; B N, 320 \mathrm{~b} / 408 \mathrm{~b})$.

Ahmed Efendi, yaklaşı iki aydan fazla bu görevleri ifa ettikten sonra bir 1syanla devlet yönetimini ele geçiren Patrona Halil'in kısa iktidar dönemine denk gelen 4 Ekim 1730 tarihinde ikinci defa mevkufatçılığa atanmış $^{16}$ ve 5 Mayıs 1731'e kadar yedi ay görev yapmıştır (A.RSK.d, 1571, 1; Afyoncu, 2004: 3; Çolak, 2003: 861).

Bir y1l kadar sonra 26 Mayıs 1732 tarihinde $^{17}$ küçük ruznamçeci olarak atandığında (A.RSK.d, nr. 1571, 11), aynı zamanda hazine kâtibidir (Hazine Kātibi Ahmed Efendi'ye küçük rūz-nāmçe: Subhî, 2007: 162). Demek oluyor ki yukarıda da ifade edildiği gibi 1715 yılında bile "çok uzun bir zamandır" ifa ettiğini zikrettiği hazine kâtipliği, diğer değişen memuriyetlerinden bağımsız olarak uhdesinde kalmaya devam

\footnotetext{
${ }^{15}$ Bu kayda göre 1720 'de ilk kez cebeciler kâtipliğine tayin edilmiş olan Ahmed Efendi, 1726 ile 1730 yılı arasındaki meçhul dört senenin herhangi bir döneminde ikinci kez cebeciler kâtibi olup azledilmiş ve daha sonra tekrar bu vazifeye atanmış olmalıdır.

${ }^{16}$ Çolak makalesinde, $B N$ 'nda Ahmed Efendi'nin 4 Rebiyülâhır 1143/17 Ekim 1730 günü mevkufatçılığa tayin edildiğini belirtmektedir (Aralık 2003: 861). Ancak Ahmed Efendi BN'daki "tārīh-i mezbūrda...bu hakīr-i pür-taksīr ikinci def'a mevküfätçı bulunup" ifadesinde, söz konusu tarihte bu göreve yeni atandığını değil, zaten bu görevde olduğunu belirtmiştir. Ayrıca iki ayrı resmî tayin kaydı (A.RSK.d, 1571, 1 ve İbnülemîn-Tevcîhât, dosya: 15, gömlek: 1656), Ahmed Efendi'nin bu vazifeye Çolak'ın verdiği tarihten on üç gün önce 21 Rebiyülevvel/4 Ekim günü atandığını göstermektedir. Keza Afyoncu da aynı kaynaklara dayanarak doğru olan 4 Ekim tarihini verir (2004: 3).

17. Vak'anüvis Subhî Mehmed Efendi, bu tarihi iki gün geç (28 Mayıs) olarak kaydetmiştir (2007: 161).
} 
etmektedir. ${ }^{18}$ Ahmed Efendi'nin küçük ruznamçecilik görevi, 20 Ekim 1732'de sona ermiştir (A.RSK.d, 1571, 11).

Tevcihat kayıtlarında, 20 Ekim 1732'deki azlinden sonra 2 Şubat 1738 tarihine kadar geçen beş yıldan fazla bir zaman zarfında hangi görevlere tayin edildiğine dair bir bilgi yoktur. Buna rağmen dönemin vakanüvisi Subhî Mehmed Efendi, 28 Şubat 1736'da Ahmed Efendi'ye cebeciler kâtipliğinin tevcih edildiğini kaydetmiştir. Bu tayin hakkında Subhî Tarihi'ndeki "Cebeciler kitābeti yine sābık Ahmed Efendi'ye" ifadesinden, meçhul olan 20 Ekim 1732-28 Şubat 1736 tarihlerinde kendisinin bir ya da birkaç kez daha cebeciler kâtipliğine atandığ anlaşılmaktadır (Subhî, 2007: 271-272).

28 Şubat'tan yaklaşı üç buçuk ay sonra 7 Haziran 1736 günü ordu-y1 hümâyûn İran seferi için Davutpaşa sahrasında toplanırken, Ahmed Efendi bu kez kalyonlar defterdarıdır. ${ }^{19}$ Bu görevi devam ederken, aynı y1l başlayan Osmanlı-Rus savaşında Karadeniz'in kuzeyini yeni bir Rus saldırısına karşı savunma faaliyetleri çerçevesinde 10 Ağustos 1736'da Kırım'a gönderilmek üzere 5000 tüfekli kalyoncu levent tahririne de memur edilmiştir (BN, 332a/420a).

Daha sonra söz konusu memuriyetten azledildiği anlaşılan Ahmed Efendi, 2 Şubat 1738 'de Anadolu muhasebeciliğine ${ }^{20}$ tayin edilmiş (A.RSK.d, 1571, 12; BN, 73b/63b) ve 16 Ocak 1739 tarihine kadar bu vazifeyi ifa etmiştir (A.RSK.d, 1571, 12). Bu süre zarfinda, kendi ifadelerine göre Mart 1738'de Sadrazam Yeğen Mehmed Paşa komutasındaki Osmanlı ordusu ile birlikte Avusturya seferine çıkmış ve haziran ayında zahire sıkıntısı baş gösterince sadrazam tarafindan Vidin'de mübayaacılardan sorumlu tutularak Tuna kıyılarından zahire toplanması işine memur edilmiştir (BN, 73b/63b). Ahmed Efendi, gecegündüz büyük gayretle çalışarak gerekli erzakı toplatmayı başarmıştır. Ayrıca anbar eminliği ile de görevlendirilmiş; hem erzak toplama

${ }^{18}$ Kâtipler, herhangi bir ağır hastalık, fevkalade bir durum ya da başka bir vazifeye tayin dişında ölene kadar kitâbet memuriyetine devam ederlerdi (Afyoncu, 2014: 118).

19 Ahmed Efendi, İran'a yapılacak harekâtın bir kara seferi olması dolayısıyla muaf tutularak İstanbul'da kalmıştır ("Bu hakīr bu vakitde kalyonlar defter-dār [ $l]$ bulunup, seferden mu'āf olunduk. Çünkü deryā seferi olsa gidebilirdik": BN, 331b/419b).

${ }^{20}$ Afyoncu, Ahmed Efendi'nin 12 Şevvâl 1150-5 Şevvâl 1151/2 Şubat 1738-16 Ocak 1739 tarihlerinde tekrar kalyonlar kâtibi/defterdarı olarak görev yaptığını belirtmesine (2004: 3) rağmen, söz konusu belgedeki kayıtlara göre bu tarihlerde kalyonlar kâtipliği değil, Anadolu muhasebeciliği yapmıştır (Muhāsebecilik-i Anadolu, Göynüklü Ahmed Efendi'ye verildi. 12 L 1150: A.RSK.d, 1571; 12). 
organizasyonunu hem de toplanan erzakın uygun şartlarda muhafazası işlerinin idaresini başarıyla yürütmüştür $(B N, 73 \mathrm{~b} / 63 \mathrm{~b})$.

Yaklaşık bir buçuk sene sonra 27 Haziran 1740'de Anadolu muhasebeciliğine yeniden atanmıștır (Muhāsebecilik-i Anadolu; sābıkā kalyonlar kātibi olan Ahmed Efendi'ye tevcīh olunmuşdur, 2 R sene 153: A.RSK.d, 1571, 12). Mecmua'da aynı yılın 28 Eylül gününe ait kayıtlar, üç ay sonra da aynı görevde olduğunu göstermektedir $(B N, 341 \mathrm{~b} / 429 \mathrm{~b})$. Tayin tarihinden hemen hemen altı ay sonra 31 Aralı 1740 günü ise hazine kâtipliği uhdesinde kalmak üzere Anadolu muhasebeciliğinden azledilmiştir $(B N, 342 \mathrm{a} / 430 \mathrm{a})$.

$\mathrm{Bu}$ tarihten itibaren yaklaşı iki yıl boyunca hangi memuriyetlerde bulunduğuna dair bir kayıt yoktur. 17 Aralık1742' $\mathrm{de}^{21}$ cebeciler kâtipliğine tayin edilmiş ve 25 Ekim 1743'e kadar vazifesini ifa etmiştir (KK.d, 0261-6: 11). Bu tarihte azledildiyse de bürokratik tayin ve azil sistemi gereği başka bir göreve atanmadığı (Afyoncu, 2004: 3) için cebeciler kitâbeti memuriyeti uhdesinde kalmaya devam etmiş olmalıdır.

\section{4. Şıkk-ı Sani Defterdarlığı ve Vefatı}

Ahmed Efendi iki y1l kadar sonra 7 Kasım 1745 tarihinde son memuriyetine, yani o güne kadar ulaşabildiği en yüksek makam olan şıkk-1 sâni defterdarlığına ${ }^{22}$ tayin edilmiştir (Defterdārlık-ı şıkk-ı sānī; sābıkā Cebeciler Kātibi Göynüklü Ahmed Efendi'ye tevcīh, fì 12 L $1588^{23}$

${ }^{21}$ KK.d, 0261-6: 11'de bu tayin tarihinin hicrî karşılı̆̆ "19 Şevvâl" olmasına rağmen Afyoncu, söz konusu tarihi kaynak belirtmeksizin "10 Şevvâl” olarak vermiştir (2004: 3) Subhî Tarihi'ne göre ise bu tarih 17 Şevvâl'dir (2007: 760). Sicill-i Osmânî'de gün belirtilmeden "Şevvâl 1155" kaydı vardır (Süreyyâ, 1308: 256). Çolak da Subhî Tarihi'ndeki 15 Aralık (17 Şevvâl) tarihini 17 Aralık olarak çevirmiş; Subhî Efendi'nin tayine dair "Cebeciler kitâbeti Göynüklü Ahmed Efendi'ye tevcîh ü ibkà olundu" yazısını ise hatalı olarak "Ahmed bin Mahmud'a cebeciler kitâbeti tevcih ve ibkâ olundu" şeklinde okumuştur (Aralık 2003: 862863).

22 Osmanlı maliye teşkilatının en büyük yöneticisi olan başdefterdarın iki yardımcısından biridir. Şıkk-1 sani defterdarlığı, Kanuni Sultan Süleyman'ın saltanatının ilk yıllarında (1525) kurulmuş ve defterdarlığın lağvedildiği 1841 yılına kadar devam etmiştir. XVII. yüzyılda ise "Anadolu defterdarı" unvanını da alarak başdefterdarın birinci yardımcısı makamına yükselmiştir. Şıkk-1 sani defterdarı, başdefterdar savaş zamanlarında ordu ile birlikte sefere gittiğinde ona vekâlet ederdi (Kütükoğlu, 1994: 95).

${ }^{23}$ Kurat ve büyük ihtimalle Kurat'1 esas alan Tertecel, Ahmed Efendi'nin ş1kk-1 sani defterdarlığına tayin tarihi olan 12 Şevvâl 1158/7 Kasım 1745 tarihini ölüm tarihi ile karıştırarak 1759 olarak vermiştir (Kurat, 1966: 262; Tertecel, 1993: 56). 
A.RSK.d, 1588, 2; İzzî, 1199: 33b; Süreyyâ, 1308: 256). Vefatına kadar her yıl aynı makama tekrar tayin edilen Ahmed Efendi, ara vermeden on dört yıla yakın bir süre şıkk-1 sani defterdarlığ makamında bulunmuştur. ${ }^{24}$ Sicill-i Osmânî de Ahmed Efendi'nin aralıksız on dört sene şıkk-1 sâni defterdarlı̆ğ ${ }^{25}$ yaptığını belirtmektedir (Süreyyâ, 1308: 256). Bununla birlikte ihtiyaç hâlinde ek olarak başka iş ya da işlerle de görevlendirilmiştir. ${ }^{26}$

Göynüklü Ahmed Efendi, hayli uzun bir ömür ve devlet hizmetinden sonra şıkk-1 sâni defterdarı olarak Mart-Nisan 1759 tarihinde vefat etmiş ve Üsküdar'da defnedilmiştir (Süreyyâ, 1308: 256). Eserine yazdığı son tarihin 24 Mart $^{27} 1759$ ("25 Receb 1172": BN, 371b/475b, str.25) olduğuna bakılırsa, yaklaşık olarak vefatından bir ay öncesine kadar mecmuasına kayıtlar düştüğü anlaşılmaktadır.

Ölümünden sonra yerine şıkk-1 sâlis defterdarı (üçüncü defterdar) olan Üsküdarî Salih Efendi tayin edilmiştir (A.DVNS.NŞT.d, 16: 242; A.RSK.d, 1588: 84; Vâsıf, 1219: 156). Yine vefatıyla birlikte çok uzun süredir uhdesinde olan hazine-i birun kâtipliği, 18 Nisan 1759 tarihinde

${ }^{24}$ İbkâen tayin edildiği tarihler: 9 Şevvâl 1159/25 Ekim 1746, 8 Şevvâl 1160/13 Ekim 1747, 10 Şevvâl 1161/3 Ekim 1748, 8 Şevvâl 1162/21 Eylül 1749, 6 Şevvâl 1163/8 Eylül 1750 (BN'nda 3 Ocak 1750: 360a/462a), 7 Şevvâl 1164/29 Ağustos 1751, 9 Şevvâl 1165/20 Ağustos 1752, 10 Şevvâl 1166/10 Ağustos 1753 (BN'nda 23 Temmuz 1753: 365a/468a), 7 Şevvâl 1167/28 Temmuz 1754 (fī 7 L yevmü'-l Cum 'a-ertesi, sā'at: 1, sene 1167...şıkk-ı sānī defterdārliğı Göynüklü Ahmed Efendi'ye ibkā: BN, 366b/469b), 6 Şevvâl 1168/16 Temmuz 1755, 6 Şevvâl 1169/4 Temmuz 1756, 5 Şevvâl 1170/23 Haziran 1757, 3 Ramazan 1171/11 Mayıs 1758 (BN, 371b/475b; Şem'dânî-zâde, 1976: 170) ya da 3 Şevvâl 1171/10 Haziran 1758 (A.RSK.d, 1588, 2, 84). Afyoncu'nun 6 Şevvâl 1168, 6 Şevvâl 1169, 5 Şevvâl 1170 ve 3 Şevvâl 1171 tevcihlerinin kaynağı olarak gösterdiği “A.RSK, nr. 1588, s. 2” künyesi yanlıştır (2004: 4); doğrusu "A.RSK.d, nr. 1588, s. 84" olmalidir.

${ }^{25}$ Osmanlı bürokrasisinde şıkk-1 sani defterdarlarının görev süreleri, diğer hacegânın yıllık tayin ve azillerinin yapıldığı şevvâl ayında sona ermez, her yıl uzatılırdı. Dolayısıyla şıkk-1 sani defterdarları uzun yıllar, hatta Ahmed Efendi'de olduğu gibi genellikle ölene kadar bu makamda kalabilirlerdi (Afyoncu, 2004: 34, 2014: 91, 100, 103).

${ }^{26}$ Mesela mecmuasında 14 Rebiyülâhır 1162/3 Mart 1749 gecesi İstanbul'da kopan büyük bir firtınanın zahire gemilerine verdiği zararı anlatırken "anbar emini" olduğunu öğreniyoruz ("Ve ba zı sefayinler dahı gark olmak üzere iken ve bu hakīr-i pür-kusūr anbār emīn [i] bulunup": BN, 359a/461a).

${ }^{27}$ Çolak, bu günü hatalı olarak "25 Mart” olarak belirtmiştir (Aralık 2003: 864). Babinger'in eserinde ise bu tarih "25.VIII.1759" (25 Ağustos) olarak verilmiştir (2000: 341).

852 
Seyyid Mehmed Hasîb Efendi'ye tevcih edilmiştir (KK.d, 0261-6: 16). O sırada şıkk-1 evvel, Müezzinzâde Halimî Mustafa Efendi'dir. ${ }^{28}$

Vefatında yüz yaşını aşmış (Süreyyâ, 1308: 256) olan Ahmed Efendi'nin devlet hizmeti de çok uzun olmalıdır. Eğer Sicill-i Osmânî'deki "mâliyyeden yetişip" ifadesi esas alınırsa; maliye kalemlerinde hizmet veren kâtip adayı şâkirdlerin 8-10 yaş gibi çocuk yaşlarda göreve başladıkları (Afyoncu, 2014: 122-123) düşünüldüğünde, vefatına kadar yaklaşık 85-90 y1l; yani neredeyse bir ömür boyu devlete hizmet etmiş olduğu ortaya çıkmaktadır. ${ }^{29}$

$\mathrm{Bu}$ kadar uzun süreli hizmetine ve tecrübesine rağmen, defterhanenin en yüksek memuriyeti olan şıkk-1 evvel (başdefterdarlık) makamına neden yükselemediği konusu ise meçhuldür. Bu durumun başlica sebebi, şıkk-1 sâniden şıkk-1 evvele tayine dair bir kuralın bulunmamasıdır (Afyoncu, 2004: 4-5). Keza, görev yaptığı yıllarda yüksek makamlardaki devlet adamlarıyla yakın ilişkiler kurmaması/kuramaması ya da özellikle sadrazamlardan yeterli ya da hiç himaye görmemesi de (Afyoncu, 2004: 4) terfi edememesinde önemli bir faktör olabilir.

Ahmed Efendi'nin devlet hizmetine dair ayrıntılı malumata rağmen, özel hayatı ve ailesi hakkında çok az bilgi vardır. Sadece bir rü'ûs defterinde, Osman Ağa isminde bir yeğeni olduğu bilinmektedir (A.RSK.d, 1570: 15). Kızı ile evlenerek damadı da olan Osman Ağa, 24 Ekim 1740-17 Mayıs 1741 ve 28 Temmuz 1754-3 Nisan 1756 tarihlerinde ${ }^{30}$ olmak üzere iki defa gurebâ-i yesâr ağalığı görevinde bulunmuştur (A.RSK.d, 1570: $15)$.

28 Göynüklü Ahmed Efendi'nin ölüm tarihi, Halimî Mustafa Efendi'nin 15 Ramazan 1171-12 Rebiyülevvel 1173//23 Mayıs 1758-3 Kasım 1759 tarihleri arasındaki üçüncü ve son şıkk-1 evvelliğine denk gelmektedir (Danişmend, 1971: 294).

29 Ahmed Efendi, neredeyse bir asırlık memuriyet hayatında; IV. Mehmed (1648-1687), II. Süleyman (1687-1691), II. Ahmed (1691-1695), II. Mustafa (1695-1703), III. Ahmed (1703-1730), I. Mahmud (1730-1754), III. Osman (1754-1757), III. Mustafa (1757-1774) olmak üzere sekiz padişah görmüştür.

${ }^{30}$ A.RSK.d, 1570, 15'de Osman Ağa'nın gurebâ-i yesâr ağalığı yaptığı tarihler 3 Şaban 1153-1 Rebiyülevvel 1154 ve 7 Şevvâl 1167-3 Rebiyülâhır 1169 olarak kaydedilmiş olmasına rağmen; aynı kaynaktan yararlanan Afyoncu, Osman Ağa'nın gurebâ-i yesâr ağalığı yaptığı ilk dönemin tarihlerini hatalı olarak 3 Şevvâl 1153-1 Rebiülevvel 1154 (22 Aralık 1740-17 Mayıs 1741); ikinci dönemin tarihlerini ise 10 Şevvâl 1166-7 Şevvâl 1168 (10 Ağustos 1753-17 Temmuz 1755) olarak vermiştir (2004: 5). 


\section{Eseri: Mecmua ${ }^{31}$}

Göynüklü Ahmed Efendi'nin neredeyse bir asırlık devlet hizmeti boyunca kaleme aldığı tek eseri "Mecmua"dır. ${ }^{32}$ Bilinen iki nüshası olan mecmuanın tam olan tek nüshası Berlin Eyalet Kütüphanesi'ndedir. ${ }^{33}$ (Berlin nüshası/ $B N$ ) Berlin nüshasının küçük bir bölümününden meydana gelen diğer nüsha (Rado nüshası/ $R N$ ) ise İstanbul Araştırmaları Enstitüsü Yazma Eserler Kütüphanesi'nde bulunmaktadır. ${ }^{34}$

\subsection{Berlin Nüshası $(B N)$}

372 varak olan $B N^{\prime}$ nın ebadı, yaklaşık olarak 300 x 200 mm'dir. Ekseriyetle nesih, kısmen de divanî, divanî kırması, talik, rık'a ve siyakat hatla kaleme alınmıştır.

Nüshada şu manzum ve mensur dinî/din dışı konulara yer vermiştir: Kronoloji, harçlar, avâid, elkap, mektup, tezkire, arz-1 hâl örnekleri, öğütler, notlar, kanunname, arazi anunları, timar sistemi, vakfiyet, kale gedikleri, Kahire-Kâbe hac güzergâhı ve menziller, Osmanl1-Avusturya sınırı civarındaki önemli kaleler ve yollar, sefer güzergâhları ve menziller, Tarih: Rus (Moskov), Mora, Avusturya (Nemçe), İran seferleri, zahire seferler için zahire toplanması ve nakli, Patrona Halil 1syanı, ahvâl-i Malta, sadaret ve vezaret makamlarına tayinler ve aziller, elçi kabulleri, elçi uğurlamaları, ziyafetler, sultan nikâhları, sûr-i hümâyûn, önemli olaylar, sene-i kebîse ile vakfe vakitlerini hesaplama formülleri, güzel kadının özellikleri, dünyaca ünlü alimler, Şam, Mısır ile doğunun ve yedi iklimin önemli şehirleri, güneş sistemindeki gezegenlerin hareketleri, Fuzulî'nin gazeli, tasavvufî şiirler, ilahî aşkın beş mertebesi, Arap atasözleri, cifr ilmi ile yazılmış kasideler ve beyitler, sırlı ayetler, el-Mevâhibü'l Ledüniyye, ebcedli tarihler, tılsımlar, muammalar, Hz. Muhammed'in hadisleri, hadis meâlleri, hilye-i Şerif, İncil'de Hz. Muhammed'in özellikleri, Hz. Ali'nin sözleri, önemli peygamberler, dört halife, sahabeler, salihler, ashâb-1 Kehf, bazı din

31 Ahmed Efendi'nin mecmuasının şekil ve içerik olarak ayrıntılı bir incelemesinin yapıldığı yeni bir çalışmamız tamamlanmak üzeredir.

32 "Dağınık şeyleri bir araya getirmek, toplamak" anlamına gelen mecmua, genelde bir ya da daha fazla yazar tarafından kaleme alınmış dinî ve din dış1 nesirlerden ya da mensurlardan meydana gelen derleme kitaplardır (Fayda, 2003: 265).

33 Staatsbibliothek zu Berlin-Preußischer Kulturbesitz, Verzeichnisses der Orientalischen Handschriften in Deutschland (VOHD) 13, 1, 446, Ms. or. quart. 1209.

${ }^{34}$ İstanbul Araştırmaları Enstitüsü Yazma Eserler Kütüphanesi, Şevket Rado Yazmaları, nr. ŞR000614. 
büyükleri, havâss için dualar, namazın farzları, ayetler, dualar, virdler, Bin Soru, Bâbu Mataru'n-Nisan, oruç fidyesi, kurban vekâleti, Şeyhülislâm Ebussuud Efendi ve Bolevî Mustafa Efendi'nin fetvaları, hastalıklar için şifalı bitkiler, ilaç ve macun terkipleri.

Çeşitli konular hakkında bilgi vermesine rağmen $B N^{\prime} n ı n$ asıl önemi, Ahmed Efendi'nin devlet hizmetinde katıldı̆̆ seferler sirasında pek çoğuna bizzat şahit olduğu, nadiren de şahit olanlardan dinlediği olayları günü gününe kaleme aldığı "Tarih"tir $(B N, 72 \mathrm{a} / 62 \mathrm{a}-75 \mathrm{a} / 65 \mathrm{a}, 178 \mathrm{a}-$ 179a/217a-218a, 215b/300b-371b/474b). Bu bölümde müellif; Moskov (Rus), Mora (Venedik), Nemçe (Avusturya) ve İran seferleri ile Patrona Halil Isyanı'nı kendi şahitlikleri ve bakış açısı çerçevesinde ayrıntılı olarak kaydetmiştir. Şahsî tanıklıklarının ürünü olan bu kayıtlar, söz konusu seferler ve olaylar hakkında diğer kaynaklarda olmayan birçok bilgi ihtiva etmektedir. Dolayısıyla yeni ve orijinal bilgileri içeren Ahmed Efendi'nin "Tarih"i, söz konusu dönemlerin askerî ve siyasî olayları için başvurulacak birincil bir kaynaktır.

\subsection{Rado Nüshası $(R N)^{35}$}

Mecmua'nın diğer nüshası olan $R N, 220$ x 165 mm ebadındadır. 1b'den başlayan ve $138 \mathrm{a}$ 'da sona eren 138 varaktan meydana gelmektedir. İri hatlı, temiz ve güzel bir nesihle yazılmıştır.

$R N$ 'nın tamamı, BN'nda 1711 Moskov seferine ve sefer sonucunda İsveç Kralı Demirbaş Şarl'ın (XII. Karl) Osmanlı topraklarından ayrılarak ülkesine dönmesine dair olayların anlatıldığı 34 varaklık (300b/215b333a/242a) tek bir konu ve bölüme karşılık gelmektedir.

Küçük hacmine rağmen $R N^{\prime}$ nın önemi, $B N$ 'nın söz konusu bölümünde eksik olan varaklardaki (312a-b/227a-b, 314a-b/229a-b, 317a-b/232a-b, 318a-b/233a-b, 319a-b/234a-b) tüm kayıtları ihtiva etmesidir. Bu kayıtlarda, Prut Seferi'nin son safhasındaki kuşatmada Rus ordusunun trajik durumu ve barış görüşmelerindeki usulsüzlükler ve ihmallere dair bilgiler bulunmaktadır (RN, 49a-53b). Bizzat Ahmed Efendi'nin ve diğer görgü şahitlerinin tanıklığıyla haberdar olduğumuz bu bilgiler/ipuçları sayesinde, 1711 Osmanlı-Rus savaşının ve barışının bilinmeyen pek çok ayrıntısını öğrenebilmek mümkün olmaktadır. $R N$ da, başka hiçbir kaynakta bulunmayan bu malzemesiyle Prut Seferi'nin, özellikle de sefere dair yukarıda zikredilen tartışmalı konuların açıklığa kavuşmasına yardımcı olacak eşsiz bir birincil kaynaktır.

${ }^{35} R N$ ve $B N^{\prime}$ nın söz konusu bölümünün transkripsiyonu, tenkitli incelemesi ve değerlendirmesinin yapıldığı bir kitap çalışması, tarafımızdan yayına hazırlanmaktadır. 


\section{Sonuç}

XVII-XVIII. yüzyıllarda yaşamış Hazine-i Birun Kâtibi ve Şıkk-1 sânî Defterdarı Göynüklü Ahmed Efendi, bir asırlık hayatı ve devlet hizmetinde kazandığ 1 engin birikimiyle çeşitli konularda önemli bir eser kaleme almış ve çağına tanıklık etmiş değerli bir devlet adamı olarak ön plana çıkmaktadır.

Çalışmamızda, Ahmed Efendi'nin hayatı ve devlet hizmetine dair şu ana kadar ulaşılabilen tüm kaynaklar üzerinde yapılan incelemeler sonucunda, literatüre kayda değer katkı sağlayacağ 1 düşünülen bazı tespitler yapılmıştır. Bu doğrultuda, müellifin hayatı hakkında Afyoncu ve Çolak'ın daha önce yaptığı çalışmalarındaki bazı bilgiler düzeltilmiş, eksik kalan kısımlar tamamlanmış, böylece daha detaylı bilgi veren bir referans kaynak oluşturulmuştur. Ayrıca Ahmed Efendi'nin özel hayatına dair günümüze çok az belge ve bilgi ulaştığı için müellifin mecmuasının bilinen iki nüshası olan Berlin ve Rado nüshaları ayrıntılı olarak taranmış, ruus kayıtları tekrar incelenmiş ve yaşadığı dönemin tarihçilerinden elde edilen bilgilerden faydalanılmıştır.

Sonuç olarak, kaleme aldığı mecmuasıyla özellikle XVIII. yüzyılın ilk yarısında Osmanlı Devleti'nin siyasi, askeri, sosyal ve iktisadi alanlarda yaşananlara 1şık tutan Göynüklü Ahmed Efendi'nin hayatı ve devlet hizmeti, mevcut kaynaklar ve arşiv belgeleriyle ortaya konulmuştur.

\section{Kaynaklar}

\section{Arşiv Kaynaklanı}

Başbakanlık Osmanlı Arşivi, A.DVNS.NŞT.d, nr. 16

Başbakanlık Osmanlı Arşivi, A.RSK.d, nr. 1562, s.118 (12 Rebiyülâhır 1117-23 Muharrem 1118/3 Ağustos 1705-7 Mayıs 1706), s.20 (8 Muharrem 1119-15 Receb 1120/11 Nisan 1707-30 Eylül 1708), s.100 (19 Şevvâl 1122/11 Aralık 1710), s.111 (11 Cemaziyülâhır 1130-15 Şevvâl 1130/12 Mayıs-11 Eylül 1718); 1570; 1571, s.1 (21 Rebiyülevvel 1143/4 Ekim 1730-27 Şevvâl 1143/5 Mayıs 1731), s. 11 (1 Zilhicce 1144/26 Mayıs 1732-1 Cemaziyülevvel 1145/20 Ekim 1732), s.12 (12 Şevvâl 1150/2 Şubat 1738-5 Şevvâl 1151/16 Ocak 1739, 2 Rebiyülâhır 1153/27 Haziran 1740), s.21 (20/22 Şevvâl 1135/24[26] Temmuz 1723, 8 Şevvâl 1138/9 Haziran 1726, 16 Muharrem 1143/1 Ağustos 1730) s.26 (11 Cemaziyülâhır 1129/23 Mayıs 1717); 1588, s.2 (12 Şevvâl 1158/7 Kasım 1745), s.84 (3 Şevvâl 1171/10 Haziran 1758).

Başbakanlık Osmanlı Arşivi, İbnülemîn-Tevcîhât, dosya: 15, gömlek: 1656 (21 Rebiyülevvel1143/4 Ekim 1730). 
Başbakanlık Osmanlı Arşivi, Kâmil Kepeci.d, nr. 261/6, s.11 (19 Şevvâl 1155-7 Ramazan 1156/25 Ekim 1743), s.16 (11 Cemaziyülâhır 1129/23 Mayıs 1717, 20 Şaban 1172/18 Nisan 1759).

Ahmed Vâsıf Efendi. (1219 h.), Mehâsinül-Âsâr ve Hakâyıku'l-Ahbâr, Cilt: I, İstanbul.

Hazîne-i Bîrûn Kâtibi Ahmed bin Mahmûd Efendi. Mecmū'a, Staatsbibliothek Preußischer Kulturbesitz, Berlin, Orientabteilung, Ms. or. quart. 1209 (Berlin Nüshast/BN).

İzzî Süleymân Efendi. (1199 h.), Târîh-i 'İzzî, Cilt: I, İstanbul.

Râşid Mehmed Efendi. (1282 h.), Tārīh, Cilt: III, İstanbul.

Silâhdâr Findıklılı Mehmed Ağa. (1928), Silâhdâr Târîhi, Cilt: II, İstanbul.

\section{Araştırma Eserler}

Afyoncu E., Ahıskalı, R. (2002), Kâtip (Osmanlı Dönemi), Türkiye Diyanet Vakfi İslâm Ansiklopedisi, Cilt: 25, s.53-55.

Afyoncu, E. (2004), Erhan, Hazine-i Birûn Kâtibi Ahmed bin Mahmud Kimdir?, Journal of Turkish Studies, Türklük Bilgisi Araştırmaları Dergisi, volume 28/1, Harward University, s.1-8.

Afyoncu, E. (2014), Osmanlı Devlet Teşkilâtında Defterhâne-i Âmire (XVI. - XVIII: Yüzylllar), Ankara.

Aktepe, M. M. (1989), III. Ahmed, Türkiye Diyanet Vakfi İslâm Ansiklopedisi, Cilt: 2, s.34-38.

Babinger, F. (2000), Osmanl Tarih Yazarları ve Eserleri, (Çev. C. Üçok), Ankara.

Çetin, A. (Aralık 1992, Ocak 1993) Bir Bâbıâlî Kâtibinin Not Defterinden I-II, TDAV, Türk Dünyası Tarih Dergisi, say1: 72, s.41-47; say1: 73, s.33-39.

Çolak, S. (1999), Die Bedeutung des Geschichtsschreibers Ahmed b. Mahmud und seines Werkes Târih-i Göynüklü als Quelle für die Geschichte des Osmanischen Reiches im 18. Jahrhundert, Berlin.

Çolak, S. (Aralık 2003), XVIII. Yüzyıl Osmanlı Tarih Yazıcılarından Hazine-i Birûn Kâtibi Ahmed bin Mahmud'un Hayatı, Belleten, say1: LXVIII/250, s.853-865. 
Danişmend, İ. H. (1971), Osmanlı Devlet Erkânı - Sadr-ı A'zamlar [Vezir-i A'zamlar], Şeyh-ül-İslâmlar, Kapdan-ı Deryalar, Başdefterdarlar, Reîs-ül-Küttablar, İstanbul.

Fayda, M. (2003), Mecmua, Türkiye Diyanet Vakfi İslâm Ansiklopedisi, Cilt: 28, s.265-268.

Kurat, A. N. (1939), Prutfälttåget och Prutfreden 1711, Karolinska Förbundets Ársbok.

Kurat, A. N. (1943), XII. Karl'ın Türkiye'de Kaldı̆ğ Zamana Ait Metinler ve Vesikalar, İstanbul.

Kurat, A. N. (1951, 1953), Prut Seferi ve Barışı, Cilt: I-II, Ankara.

Kurat, A. N. (1966), Hazine-i Bîrun Kâtibi Ahmed bin Mahmud'un (1123-1711-Prut) Seferine Ait Defteri, AÜDTCF Tarih Araştırmaları Dergisi, Cilt: IV, sayı: 6-7, s.357-426.

Kütükoğlu, M. S. (1994), Defterdar, Türkiye Diyanet Vakfi İslâm Ansiklopedisi, Cilt: 9, s.94-96.

Mehmed Süreyyâ. (1308 r.), Sicill-i Osmânî yâhûd Tezkire-i Meşâhîr-i Osmâniyye, Cilt: I, İstanbul.

Orhonlu, C. (1998), Hazîne, Türkiye Diyanet Vakfi İslâm Ansiklopedisi, Cilt: 17, s.130-133.

Şem'dânî-zâde Findıkllı Süleyman Efendi Târihi-Mür'i't-Tevârih. (1976), Cilt: I, (Yay. M. Münir Aktepe), İstanbul.

Tertecel, A. (1993), Un İzvor Otoman Necunoscut Istoriografiei Noastre: „Jurnalul” (Defter) Lui Ahmed bin Mahmud (Secretar al Vistieriei Otomane) Privind Campania Militara a Inaltei Porti Din Anul 1711 in Moldova, Caietele Laboratorului de Studii Otomane, nr. 2, s.55132.

Tertecel, A. (1994), Anexele Jurnalului Lui Ahmed Bin Maiiniud Privind Campania de la Prut (1711), Academia Romănâ Institutul de Istorie, Nicolae Iorga, Studii Şi Materiale de Istorie Medie, Volumul XII, s.201-214 (1-14).

Uzunçarşı11, İ. H. (1982), Osmanlı Tarihi, Cilt: IV/1, Ankara.

Uzunçarşı11, İ. H. (1984), Osmanlı Devletinin Merkez ve Bahriye Teşkilâtı, Ankara. 
Vak'anüvis Subhî Mehmed Efendi (2007), Subhî Tarihi-Sâmî ve Şâkir Tarihleri ile Birlikte (İnceleme ve Karşılaştırmalı Metin), (Haz. M. Aydıner), İstanbul.

Ekler 1: (Ahmed Efendi'nin hazine-i birun kâtipliğine dair)

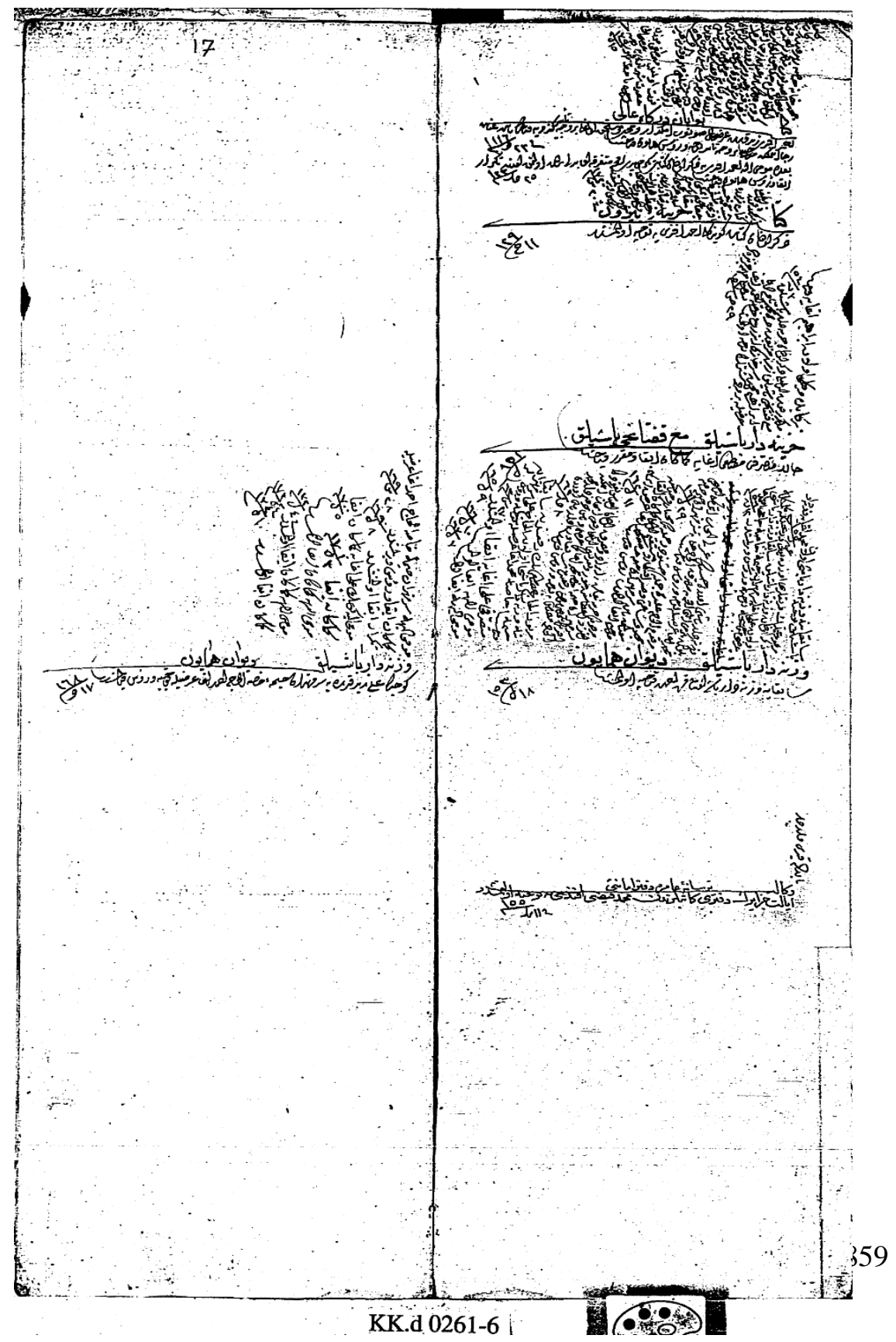


BOA, KK.d., 0261-6, 16-17

Ekler 2: (Ahmed Efendi'nin küçük ruznamçeciliğe tayini hakkında)

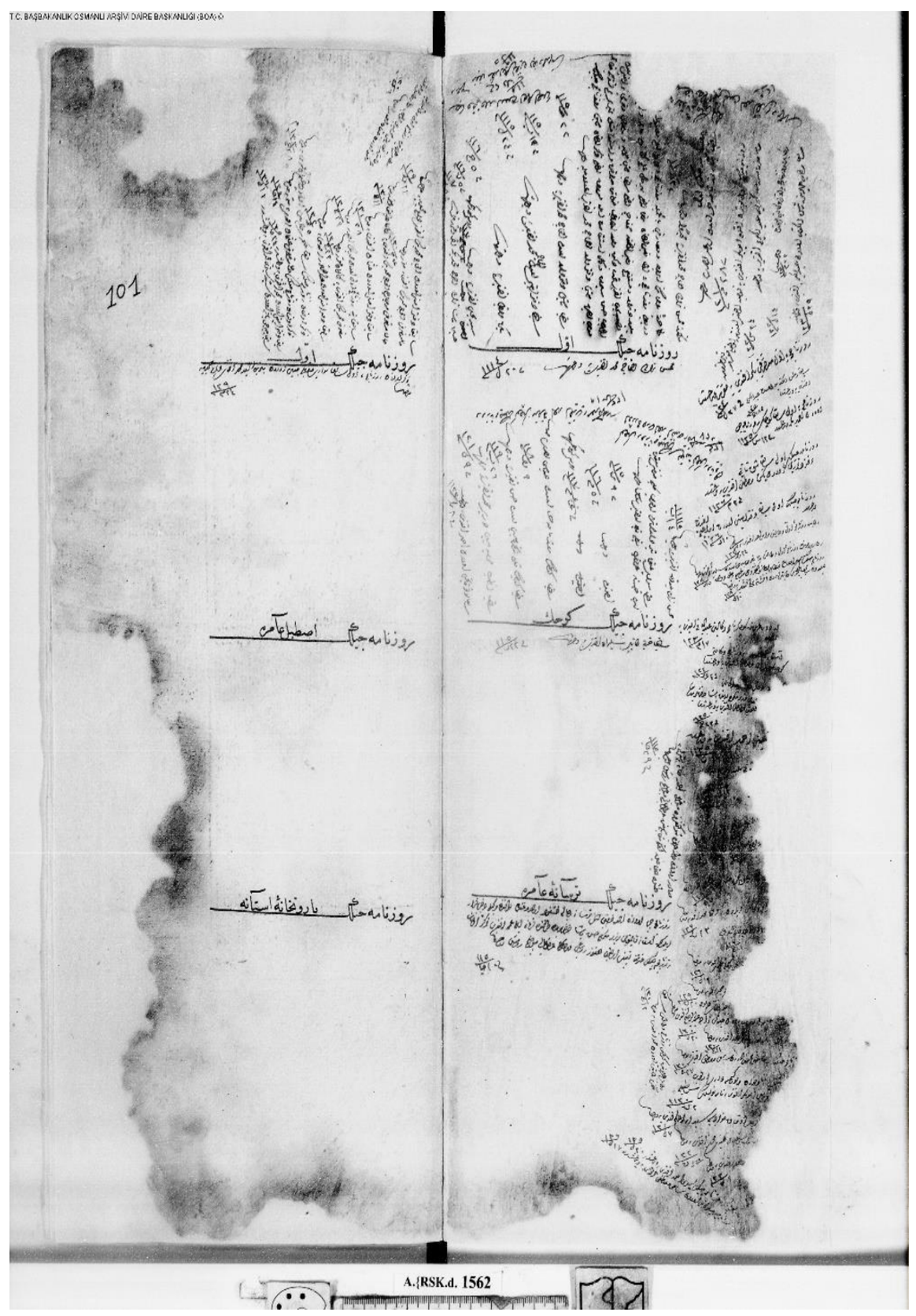


BOA, A.RSK.d, nr. 1562, 100-101

Ekler 3: (Ahmed Efendi'nin Anadolu muhasebeciliğine tayini hakkında)

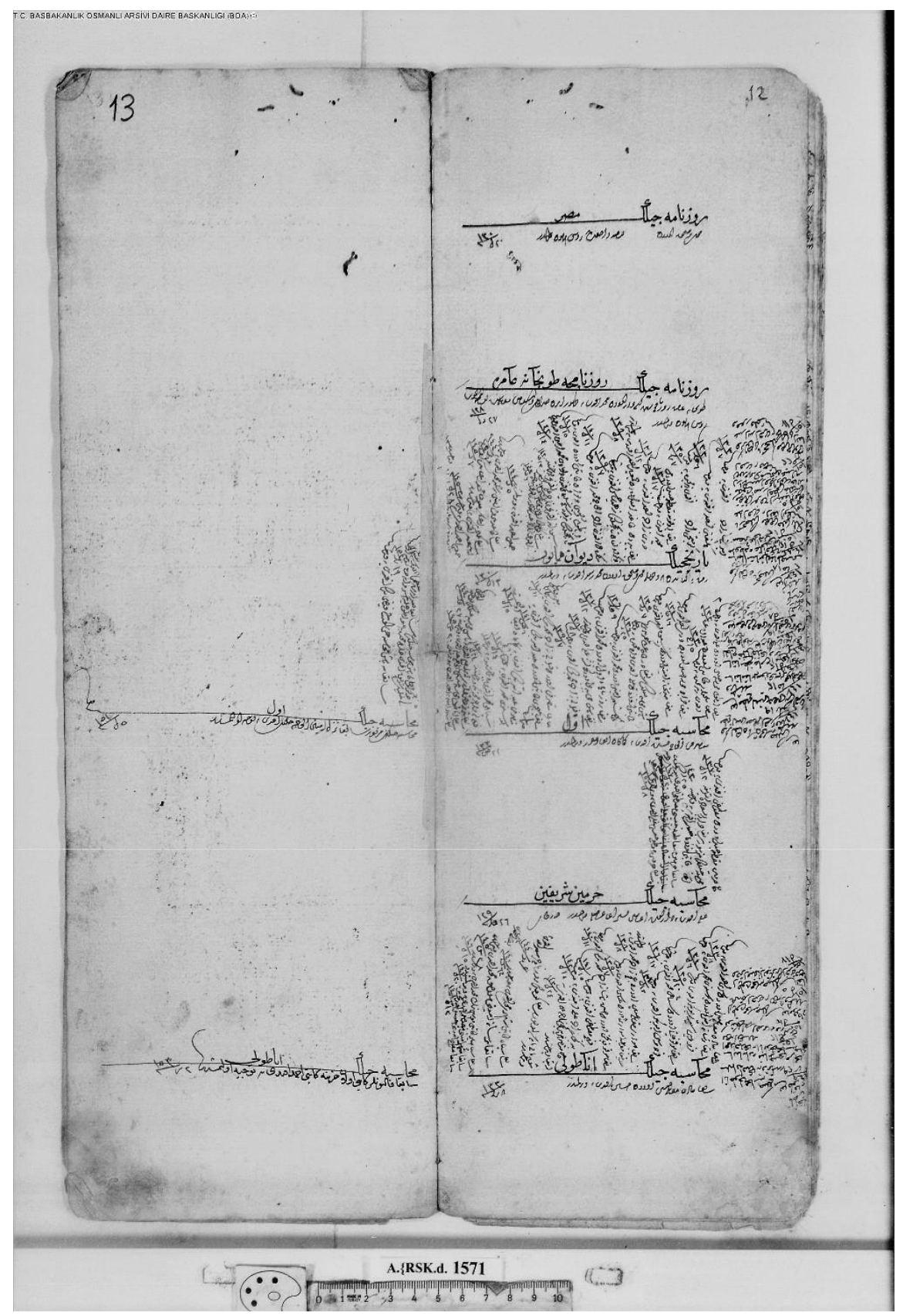


BOA, A.RSK.d, 1571, 12-13

Ekler 4: (Ahmed Efendi'nin cebeciler kitabetine tayinine dair)

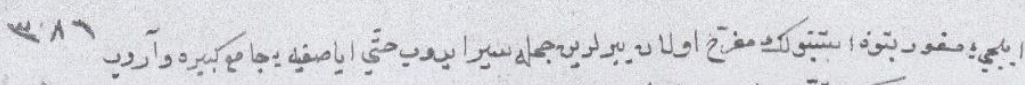

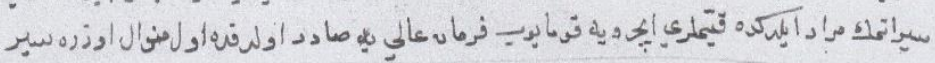

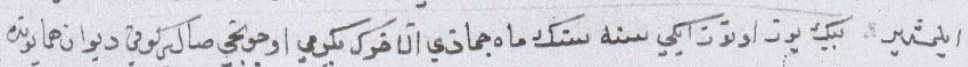

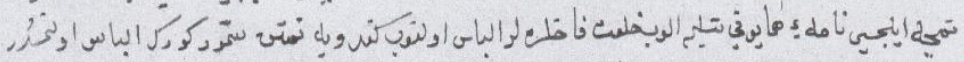

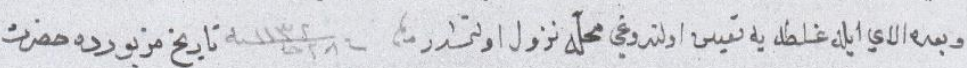

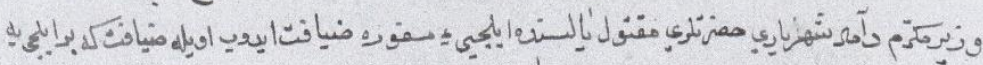

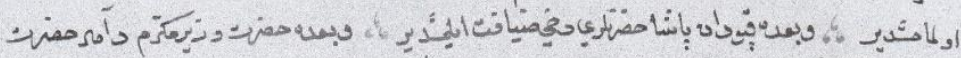

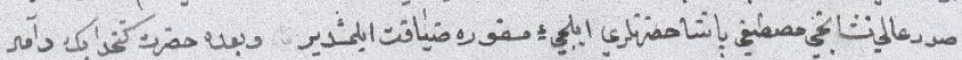

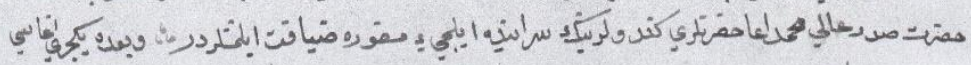

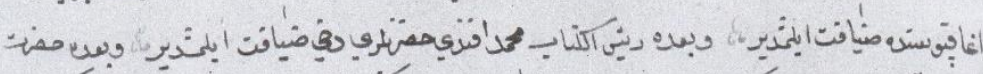

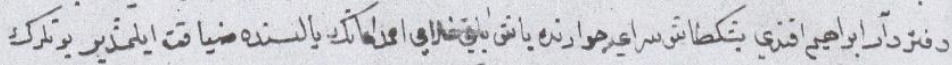

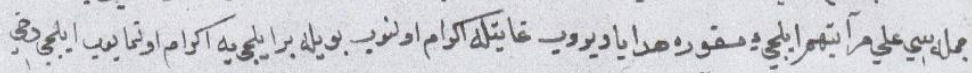

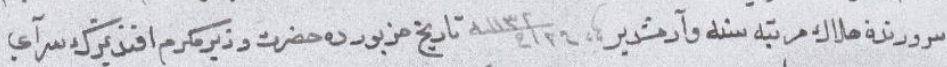

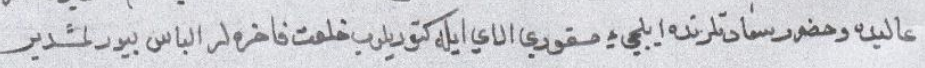

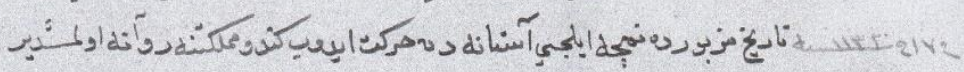

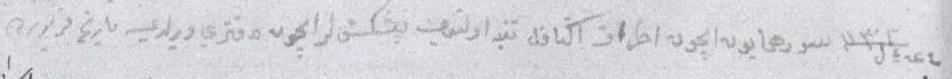

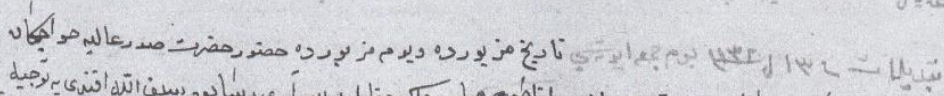

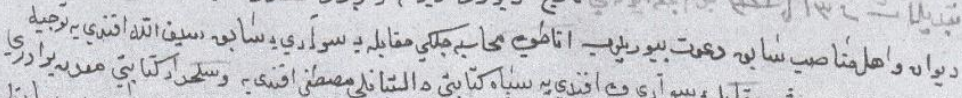

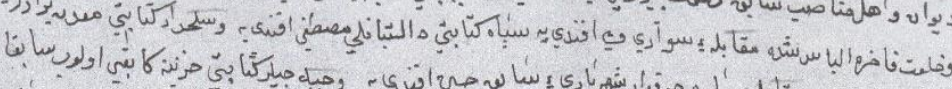

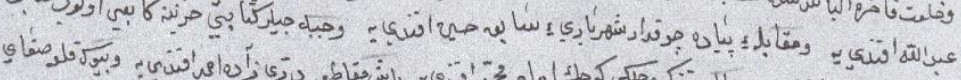

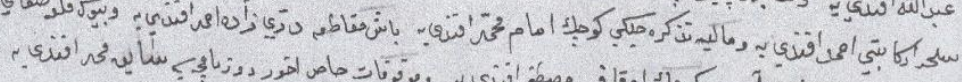

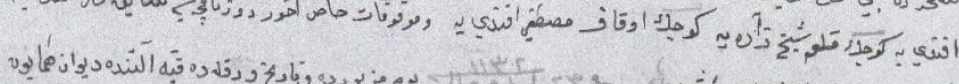

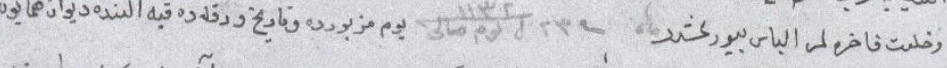

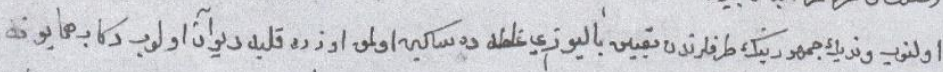

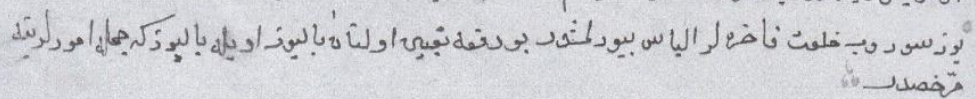


BN (Местиа), 296а

Ekler 5: (Ahmed Efendi'nin mecmuaya düştüğü son tarihe dair)

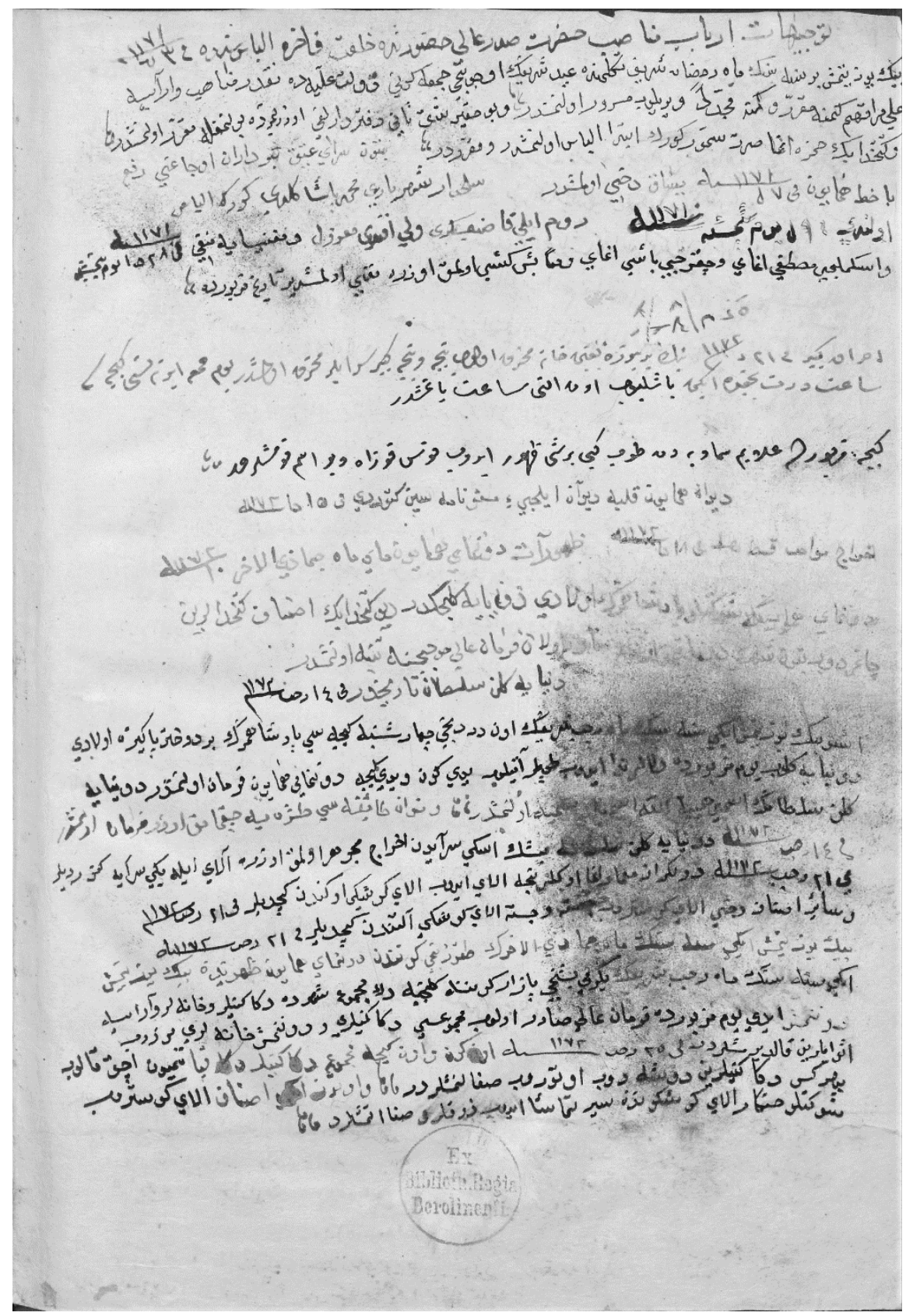

BN (Местиа), 371b/475b 